UDC 340.1

DOI https://doi.org/10.32849/2663-5313/2021.11.06

Dmytro Yasynok,

Postgraduate Student, Assistant at the Faculty of Law, Sumy National Agrarian University, 160, Herasyma Kondratieva street, Sumy, Ukraine, postal code 40000, supernova1605@gmail.com ORCID: orcid.org/0000-0003-0862-999X

Yasynok, Dmytro (2021). The concept of judicial lawmaking and its limits in civil proceedings of Ukraine. Entrepreneurship, Economy and Law, 11, 48-53, doi https://doi.org/10.32849/2663-53 $13 / 2021.11 .06$

\title{
THE CONCEPT OF JUDICIAL LAWMAKING AND ITS LIMITS IN CIVIL PROCEEDINGS OF UKRAINE
}

Abstract. The purpose of this article is to consider the most controversial and poorly studied concept judicial lawmaking and its limits in the civil procedural law of Ukraine. Although the concept ofjudicial lawmaking is not enshrined in the Civil Procedural Code of Ukraine as revised in 2017, the grounds for such law enforcement actions are specified by the Grand Chamber of the Supreme Court. These grounds are proxy and related to "exclusive legal problems" that make it possible to "ensure the development of law and the formation of a unified law enforcement practice" (as stated in para. 5 of Art. 403 of the Civil Procedural Code of Ukraine). Moreover, it is judicial lawmaking that underlies judicial precedents. Referring to these grounds, it is possible to hold that Ukraine has taken the first step towards the introduction of case law into justice. Today, such a step plays a triple role: a) to provide safety measures for the legislator against the possibility of legislative gaps; b) to shape a single law enforcement practice; c) to develop law. Thus, Ukraine is gradually straying from Soviet normativism and tends towards the practice of living justice, when legal positions, legal analogies, judicial lawmaking take place in the consideration of a particular case. The convergence of common law and continental law is evolving steadily in Ukraine due to the shift of that sort of methodological approach. This trend is observed not only in Ukraine but also in Estonia, Latvia, Lithuania, and Georgia. Thus, in the medium term, the legislator and, subsequently, the scientific doctrine will have to recognize the existence of judicial lawmaking, which is the basis of judicial precedents which should be recognized as a source of law. Therefore, the issue of judicial lawmaking will gain a new impetus in further research.

Research methods. The contribution is based on the complex application of general scientific and special methods of research and cognition. In this context, the systemic-functional method allowed studying judicial lawmaking and its limits as a procedural law phenomenon, which is the fundamental principle of the formation of future case law in civil proceedings of Ukraine. The historical method was used to clarify the previous historical conditions that became the basis for the emergence and development of judicial lawmaking and, subsequently, influenced the establishment of some legal traditions. The dialectical method allowed elucidating the unity and contradictions of the process in judicial lawmaking, which made it possible to build a holistic system of ideas about the substantive and legal essence of such a phenomenon as judicial lawmaking and its limits.

Results. The paper proves that judicial lawmaking as a procedural law category is an integral part of court precedents, the application of which in overcoming legislative gaps is an inevitable issue today. This means that the legislator is gradually forgoing the postulates of continental law in civil proceedings, and hence procedural law, by directing towards common law.

Conclusions. The court, being an independent branch of state power, is designed to resolve various legal disputes between individuals and legal entities, as well as the state, thus eliminating tensions in public relations. Although the court does not create the law, it finds some legislative gaps (cracks) or outdated legislation while hearing court cases. Consequently, it is forced to overcome such legislative challenges by creating new legal formulas, concepts or provisions, which on the one hand develop law, and on the other - form a single law enforcement practice. Thus, judicial lawmaking encourages today's doctrinal research to start not from theory to practice, but on the contrary - from practice to research theory of some provisions or concepts. This trend is peculiar not only to Ukraine but also to the European doctrine of the international case law of the European Court of Human Rights. At the same time, judicial lawmaking is not a limitless concept. It takes place whenever and where it is necessary to secure the legislator against legislative complications or inconsistencies. In this part, there is a list of conditions specified in this work which objectively restrict judicial lawmaking.

Key words: judicial lawmaking, limits of judicial lawmaking, legislative gaps (cracks). 


\section{Introduction}

Judicial lawmaking as a procedural law category always takes place in that part where legislative inconsistencies or legislative gaps (cracks) in both substantive and procedural law are manifested in considering civil cases. This trend occurs against the background of many economic and legal reforms requiring extensive law-making activity, which focuses on immediate legislative support of such reforms that causes objective stylistic and textual errors, legislative gaps (cracks). This appears at the stage of the court hearing of civil disputes.

Since courts are not entitled to deny a person justice due to a lack of legislation, its undue reliance on cases, or disputability, the courts are bound to settle a dispute between the parties by relying on the most accurate legal qualification of contentious relations. In this regard, courts often face challenges in their work. The above is driven by the extremely rapid scientific and technological development, which also contributes to the rapid development of social relations in all spheres of human life that entails the accelerated obsolescence of substantive law and the lack of new legal rules, encouraging the court to judicial lawmaking under particular legal conditions that always accompany such a process.

Judicial lawmaking and its features have been covered in research by such specialists as Ya. Romaniuk (2016), N. Stetsyk (2019), P. Komar (2020), S. Zapara (2021), I. Kravchenko (2021), O. Dashkovska (2021), and Yu. Riabchenko (2021). Other priority studies somehow have addressed judicial lawmaking and its limits.

2. Historical and legal analysis of the institute of judicial lawmaking

The court as a universal state legal institute resolves all existing civil disputes in the state, regardless of whether they are statutory regulated or not. The system-wide approach to justice is inherent in the judicial systems of all world countries, and Ukraine is no exception. Another question is, what procedural tradition of civil law disputes has historically developed in a particular state? What do such traditions have in common, and is there a process of their gradual convergence in today's realities? These and other issues have been repeatedly discussed in studies by both young and prominent scholars. However, given their extensionality, complexity, judicial lawmaking and its boundaries, they have been ignored due to new features emerging during such studies.

Society and the judiciary first encountered judicial lawmaking in medieval England, where the royal crown courts, because of the incompetence of royal power, were forced to combine state legislation and local well-established customs through their lawmaking in considering civil disputes. Thus, specific legal formulas, which were further used in the legal mechanism for litigation, were created. The legal formulas (legal positions) were applied as legal "patterns" to similar disputes, and if they coincided, the case was considered by analogy. Time after time, courts traditionally referred to the legal positions already tested by the court by treating them as laws. Consequently, the doctrinal formula "stare decisis", which means "to stand by things decided", gradually crystallized the justice of England (Carner, 1995, p. 953).

That gave rise to the emergence of case law in England. It was called the Anglo-Saxon legal family in the countries where it spread. At the same time, it was called common (Bernkhem, 1999, p. 54), living (Shevchuk, 2007, p. 24), or natural (Marchuk, Nikolaieva, 2004, p. 81), and judicial law (Shevchuk, 2007, p. 24) as it is based on judicial lawmaking, which today is considered a separate procedural category.

As for Soviet Ukraine, the state kept a tight rein on courts, because the court was not recognized as authority obeying not the law but proletarian expediency grounded on the principle of socialist legality. That sort of legality hinged on the force of dogma, cult of the leader, and forceful interference of the state in all civil-law relations. Thus, the characteristic feature of continental law is the availability of the sustainable case law that does not rely on judicial lawmaking, which allows stepping back from legal positions of the past, but on the exclusive interpretive law enforcement of outdated legal rules. Until recent times, the Plenum of the Supreme Court of Ukraine has acted as the classic moderator of this methodology. There is no doubt the Plenum was not a court authority, but its "guiding explanations" were binding on the lower courts, although they had the status of legal recommendations.

3. Judicial lawmaking as a way to fill legislative gaps (cracks)

It is beyond argument that the concept "judicial lawmaking" is more a legal fiction, as the court does not create law. The court interprets it both within the framework of the substantive legal essence of a particular rule of law and legal principles, common grounds of substantive law, and its objectives to develop new legal formulas. Therefore, the court fills legislative gaps between legal rules due to substantive and legal disparity between them, or when the content of a particular law rule is stylistically, and accordingly 
legally, inconsistent with the general essence of the law ensuing in a legal gap in the substantive and legal essence of such rules. This means that in the presence of legislative gaps (cracks), the court shapes a new legal understanding of both individual concepts, which are peculiar to legal relations in dispute, and provisions that justify the grounds for filling such gaps. Moreover, based on exclusive, logical-legal thinking and interpretive methods, the court creates legal formulas for "general principles of substantive law and the principles of law and its institutions" (Kaptsova, 2021, p. 94), the principles of morality and social values to resolve the dispute on the one hand and fill legislative gaps (cracks) on the other.

At the same time, judicial lawmaking, its algorithm, and justification techniques for filling legislative gaps (cracks) in consideration of civil cases in courts of general jurisdiction allow developing both individual law branches and law in general. Thus, on the one hand, judicial lawmaking can be considered as a source for the development of the theory of law and on the other, as a way to form a unified law enforcement practice. It is the basis on which a new development course of both substantive and procedural law is being formed in Ukraine. The course follows the formula: not from theory to practice, but from practice to theory. Although law has historically performed long-term tasks, it, like any hypercomplex system, has some inaccuracies, inconsistencies, which justice later identifies and eliminates. This process is called filling legislative gaps (cracks), which the court identifies when considering the case on merits. The reasons for the emergence of legislative gaps (cracks) lie in the legislative process. The legislator always discusses and adopts each legal rule separately in a bid to anticipate all possible directions of the development of public relations. However, regardless of such meticulous work, courts deal with extra-statutory cases in the practical dimension of law enforcement practice.

4. Judicial lawmaking in the field of judicial reform

Judicial reform, which has been launched in Ukraine, depends today not only on the judiciary's upgrade but also on the adoption of new approaches in law enforcement practice, which regards judicial lawmaking as a process of filling legislative gaps (cracks) in the law enforcement practice of civil procedure.

All of these things are the grounds that motivate the court to judicial lawmaking, which acts as legal insurance of the legislator against legislative gaps (cracks) or untimely modifications, additions, or clarifications of outdated legislation. At the same time, this is not only about the legislator. This refers to quite rapid development of social relations stipulated by constant innovations in the economy, technology, property, finance and information spheres, as well as innovations in human behavior.

The above tendencies are peculiar today both to Ukraine and continental Europe where, as well as in Ukraine, the classic concept of legal positivism - justice was limited to the content of the legal rule- prevailed for a long time. Consequently, courts mechanically applied the "text of a law that excluded any creative role of judges" (Koziubra, 2016, pp. 38-48).

One might jump to the conclusion that the legislator will expand the source base of procedural laws and thus recognize the law-making practice of the Supreme Court as a source of law; and as well as in European countries, there will be a shift from the positivist theory of law to common law since it allows law and its theoretical positions to develop. For the sake of justice, it should be noted that the legislator indirectly admits the existence of judicial lawmaking as a growth area of our justice if there is "an exclusive legal problem" in order "to develop law and form a unified law enforcement practice" (para. 5 of Art. 403 of the Civil Procedural Code of Ukraine). This can be understood as the legislator set about paying attention to natural law and its component - judicial lawmaking, which is always in close contact with reality (Van Caeudem, 1992, p. 170). Thus, one currently can state that the judgments of the Supreme Court, under their binding legal positions, de facto act as judicial precedents, because "in choosing and applying legal rules to the disputed legal relations, the court has regard to the conclusions about the application of the relevant legal rules set out in the judgments of the Supreme Court" (para. 4 of Art. 263 of Civil Procedural Code of Ukraine).

What is "judicial lawmaking" as a procedural category? This question provokes a range of scientific discussions, and the first question in this discussion is as follows: what branch of the judiciary is entitled to administering lawmaking? Some scientists, incl. A. Norkin, B. Malyshev, and M. Yasynok, believe that courts of all instances are entitled to judicial lawmaking, as courts of all levels "are prohibited from refusing to consider the case on the grounds of absence, incompleteness, inconsistency of the legislation governing disputed relations" (para. 10 of Art. 10 of the Civil Procedural Code of Ukraine). The article's author supports the above position, but he understands that the legal formulas specified by the court in filling legislative gaps (cracks) are definitive since 
they can be changed or repealed on appeal or in cassation. However, the courts of all instances have the relevant right, albeit indirectly.

Another group of scholars, M. Marchenko, O. Popov, S. Kyvchuk, believe that the Supreme Court should be the only subject of judicial lawmaking in our country, because following para. 5 of Art. 403 of the Civil Procedural Code of Ukraine, only the Supreme Court is authorized to ensure the development of law to form a single law enforcement practice in the presence of an exceptional legal problem. The beforementioned means that the very Supreme Court has the right to judicial lawmaking and thus, the formation of new legal concepts, which allow filling legislative gaps (crack) that are noticed in the current legislation during the trial of civil cases. There is no doubt that the Supreme Court, as the highest judicial body, should have the right to judicial lawmaking, thus developing law from its practice to theory.

5. Judicial lawmaking of the European Court of Human Rights and its particularities

If one compares the approach of the Supreme Court in judicial lawmaking with the caselaw of the European Court of Human Rights, which often relies on the lawmaking process, one can point out that such lawmaking is grounded on an expanded interpretation of the European Convention on Human Rights (hereinafter - the Convention). The peculiarity of such interpretation, which usually moves to judicial lawmaking, is that the European Court has to go beyond the substantive and legal essence of the Convention because its rules are abstract, and therefore not specific, as set out in a synthetical form. As a result, the European Court of Human Rights notes that its judgments are not judicial precedents. At the same time, it concurrently admits that its law-making is compulsory, as neither the Convention nor its protocols are of a clarification nature. Such an approach to the statement of the Convention's rules relies on factual circumstances, as the European Court is not bound by the national law of the European Union. Consequently, when considering cases of protection of individual rights, freedoms and interests, the court should manage to interpret the Convention extensively. It acts so in the practical dimension because the Convention does not consolidate a set of concepts concerning, for example, housing (case "Prokopovich v. Russia", judgment as of November 18, 2004) (European Court of Human Rights, 2004), reasonable terms (case "Zimmermann and Steiner v. Switzerland", judgment as of June 20, 1983) (European Court of Human Rights, 1983), property (case “Marx v. Belgium”, judgment as April 27, 1979)
(Fulei, 2008, p. 43). etc. Consequently, in order to overcome legislative gaps, the European Court, driven by the law-making process, goes beyond the substantive and legal scope of the conventional rules and thus directly forms and enshrines the relevant concepts in its judgments. Such decisions are recognized both in continental law and common law of Ukraine. For these reasons, the European Court in its judgments gradually combines both common and continental law generating such a procedural synthesis in which, along with the classics of continental law, European case law is formed incl. its: a) lawmaking; b) unification; c) recurrence; d) a single law enforcement practice: e) a single growth area of European law.

Thus, an obvious fact is that in considering civil cases, each court in its procedural work always somewhat deals with judicial lawmaking, as social development constantly needs new legal concepts, provisions, and therefore, the advancement of science - the renewal of judicial practice corresponds to the conditions of social development in which they are formed. The paradox of law is that law regulates social relations, but it cannot anticipate them.

\section{Judicial lawmaking and its limits}

There is no doubt that the right to judicial lawmaking is not a court's permission for infinity, illogicality, and unreasonableness. Judicial lawmaking shall always have some limits stipulated by particular conditions, and it is conditions that create law-making restrictions. Therefore, judicial lawmaking is only practicable to:

a) legal relations that have already accomplished their active function and passed into the stage of disputed stagnation and thus, have become the subject of litigation;

b) judicial lawmaking can take place only within the procedural form of court hearings and can never take place outside;

c) judicial lawmaking may be carried out only by a court which considers the case on the merits on appeal or in cassation;

d) judicial lawmaking may not go beyond those legal relations that are considered by the court;

e) judicial lawmaking may not take place in that part which contains legal rules governing the disputed legal relations;

f) judicial lawmaking cannot occur towards the matter in dispute, which is excluded from civil circulation;

g) judicial lawmaking cannot occur in the presence of legislative prohibitions.

7. Conclusions

The court, being an independent branch of state power, is designed to resolve various 
legal disputes between individuals and legal entities and the state, thus eliminating tension in public relations.

Although the court does not create law, it identifies some legislative gaps (cracks) or outdated legislation while considering court cases. Consequently, it is forced to respond to such legislative challenges by creating new legal formulas, concepts, or provisions, which on the one hand, advance the law and on the other shape a single law enforcement practice. Thus, judicial lawmaking encourages today's doctrinal research to act not from theory to practice, but on the contrary - from practice to the theory of study of particular provisions or concepts. This trend is peculiar to Ukraine and the European doctrine of the international case-law of the European Court of Human Rights.

At the same time, judicial lawmaking is not a limitless concept. It takes place whenever and where it is necessary to secure the legislator against legislative complications or inconsistencies. In this part, there is a list of conditions specified in this work, which objectively restrict judicial lawmaking.

\section{References:}

Bernkhem, V. (1999). Vstup do prava ta pravovoi systemy SShA [Introduction to US law and legal system], transl. from English. Kyiv: Publishing house "Ukraine", 555 p. (in Ukrainian).

Carner, B. (1995). Dictionary of Modern Legal Usage. New York: Oxford University Press, 953 p. (in English).

European Court of Human Rights (2004). Rishennia Yevropeiskoho sudu z prav liudyny u spravi "Prokopovych proty Rosii" vid 18 lystopada 2004 r. [Judgment of the European Court of Human Rights in the case of "Prokopovich v. Russia" of November 18, 2004]. Retrieved from: https:// zakon.rada.gov.ua/laws/show/980_233\#Text (in Ukrainian).

European Court of Human Rights (2004). Rishennia Yevropeiskoho sudu z prav liudyny u spravi "Tsymerman i Shtainer proty Shveitsarii" vid 20 chervnia 1983 r. [Judgment of the European Court of Human Rights in the case of "Zimmermann and Steiner v. Switzerland" of June 20, 1983]. Retrieved from: https://zakon.rada.gov.ua/laws/show/980 417\#Text (in Ukrainian).

Fulei, T. (2008). Poniattia "maino" v praktytsi Yevropeiskoho Sudu z prav liudyny [The concept of "property" in the case law of the European Court of Human Rights]. Visnyk Verkhornoho Sudu Ukrainy, no. 3, p. 43-48 (in Ukrainian).

Kaptsova, T. (2021). Prohalyna v pravi yak peredumova zastosuvannia yurydychnoi analohii [A gap in the law as a prerequisite for the application of legal analogy]. Pidpryiemnytstvo hospodarstoo i pravo, no. 3, p. 90-98 (in Ukrainian).

Koziubra, M. (2016). Sudova pravotvorchist: analohiia chy imanentna vlastyvist pravosuddia [Judicial lawmaking: analogy or immanent property of justice]. Pravo Ukrainy, no. 10, pp. 38-48 (in Ukrainian).

Marchuk, V., Nikolaieva, L. (2004). Narysy z teorii prava [Essays on the theory of law]. Kyiv: Istyna, 200 p. (in Ukrainian).

Montesk'e, Sh.-L. (1964). O dukhe zakonov [On the spirit of laws]. Moscow, 600 p. (in Russian).

Shevchuk, S. (2007). Sudova pravotvorchist ta sotsialna shkola prava [Judicial legislation and sociological school of jurisprudence]. Visnyk Verkhornoho sudu Ukrainy, no. 1, pp. 24-29 (in Ukrainian).

Van Caeudem, R. (1992). An Historical introduction to Private Law. Cambridge, 215 p. (in English).

\section{Дмитро Ясинок,}

аспірант, асистент юридичного факультету, Сумський нащіональний аграрний університет, вулиия Герасима Кондратьєва, 160, Суми, Україна, індекс 40000, yasynok5@gmail.com

ORCID: orcid.org/0000-0003-0862-999X

\section{ПОНЯТТЯ СУДОВОЇ ПРАВОТВОРЧОСТІ ТА ЇЇ МЕЖ У ЦИВІЛЬНОМУ СУДОЧИНСТВІ УКРАЇНИ}

Анотація. Мета роботи полягає в дослідженні дуже дискусійного й малодослідженого поняття судової правотворчості та ії меж у цивільному процесуальному праві України. Незважаючи на те, що поняття судової правотворчості в Цивільному процесуальному кодексі України (у редакції 2017 р.) не має свого нормативного закріплення, проте підстави для таких правотворчих дій на рівні Великої Палати Верховного Суду все ж зазначені. І хоча ці підстави мають опосередкований зміст та стосуються «виключних правових проблем», що дають можливість забезпечити «розвиток права 
та формування єдиної правозастосовної практики» (як зазначено в ч. 5 ст. 403 Цивільного процесуального кодексу України), проте саме така опосередкованість відкриває шлях до судової правотворчості. Окреслений підхід до судової правотворчості лежить в основі судових прецедентів. 3 огляду на зазначені підстави можна говорити про те, що в Україні зроблено перший крок до впровадження у правосуддя прецедентного права. Сьогодні цей крок відіграє потрійну роль: а) страхує законодавця на випадок законодавчих прогалин; б) формує єдину правозастосовну практику; в) розвиває право. Таким чином, Україна поступово відходить від радянського нормативізму та приходить до практики живого правосуддя, коли правові позиції, правові аналогії, судова правотворчість мають місце під час безпосереднього розгляду конкретної судової справи. Саме завдяки змінам цього методологічного підходу в Україні поступово відбувається зближення загального й континентального права. Така тенденція має місце не лише в Україні, а й в Естонії, Латвії, Литві, Грузії. Таким чином, уже в середньостроковій перспективі законодавець, а отже, і наукова доктрина будуть змушені визнати наявність у правосудді судової правотворчості, що є основою судових прецедентів, які необхідно буде визнавати джерелом права, а відтак питання судової правотворчості отримає новий імпульс у подальшому науковому дослідженні.

Методи дослідження. Роботу виконано на підставі комплексного застосування загальнонаукових і спеціальних методів дослідження й пізнання. Так, системно-функціональний метод дав змогу дослідити судову правотворчість і їі межі як процесуально-правове явище, яке є фундаментальною основою формування майбутнього прецедентного права в цивільному судочинстві України. Історичний метод застосовувався для з'ясування тих історичних умов, які стали підставами для виникнення й розвитку судової правотворчості та надалі вплинули на формування певних правових традицій. Діалектичний метод дав можливість розкрити єдність і суперечливість процесу у сфері судової правотворчості, що дало змогу скласти цілісну систему уявлень щодо змістовно-правової суті такого явища, як судова правотворчість, і її меж.

Результати. У роботі доведено, що судова правотворчість як процесуально-правова категорія $€$ невід’ємною складовою частиною судових прецедентів, застосування яких у питаннях подолання законодавчих прогалин $€$ на сьогодні невідворотним питанням. Це означає, що законодавець поступово відходить від постулатів континентального права в цивільному судочинстві та спрямовує свої погляди (а отже, і процесуальне законодавство) у напрямі загального права.

Висновки. Суд, як самостійна гілка державної влади, покликаний урегульовувати різноспрямовані правові спори між фізичними та юридичними особами, а також між ними й державою. У такий спосіб він усуває напругу в суспільних відносинах. Незважаючи на те, що суд не творить право, під час розгляду судових справ він виявляє ті чи інші законодавчі прогалини (щілини) або застаріле законодавство, а тому вимушений долати такі законодавчі негаразди за рахунок створення нових правових формул, понять чи положень, які, з одного боку, розвивають право, а з іншого - формують єдину правозастосовну практику. Таким чином, судова правотворчість спонукає до здійснення сьогоднішніх доктринальних досліджень тих чи інших положень або понять у напрямі не від теорії до практики, а навпаки - від практики до теорії. Ця тенденція характерна не лише для України, а й для європейської доктрини у сфері міжнародної судової практики Європейського суду з прав людини. Водночас судова правотворчість не є безмежним поняттям. Воно має місце лише там і тоді, коли виникає необхідність страхування законодавця від законодавчих ускладнень чи неузгодженості. Щодо цього є цілий перелік умов, зазначених у представленій роботі, які об'єктивно обмежують судову правотворчість.

Ключові слова: судова правотворчість, межі судової правотворчості, законодавчі прогалини (щілини).

The article was submitted 28.10.2021

The article was revised 18.11.2021

The article was accepted 09.12.2021 